J. clin. Path. (1949), 2121.

\title{
THE MICROBIOLOGICAL ASSAY OF RIBOFLAVIN AND NICOTINIC ACID IN URINE
}

\author{
BY \\ JOSEPH FITZPATRICK AND SIDNEY LIONEL TOMPSETT \\ From the Biochemical Department, Royal Infirmary, Glasgow
}

(RECEIVED FOR PUBLICATION, DECEMBER 16, 1948)

Riboflavin and nicotinic acid may be determined by (1) biological assay, using animals, (2) chemical methods, colorimetric or fluorometric, (3) microbiological assay, using bacteria of known nutritional requirements.

The biological properties of these two vitamins were established in animal experiments, and for a time similar assay methods were used to assess their concentrations in various types of materials. Such methods are time-consuming, require specialized experience, and are not particularly sensitive or accurate. Chemical methods which were developed later still lack sensitivity and are subject to inaccuracies owing to the necessity of a number of manipulations to remove interfering substances. Within recent years much information has been obtained with regard to the nutritional requirements of many species of bacteria. It has been shown that many require certain members of the vitamin B complex for optimum growth. When other nutritional requirements are present in excess, growth of a particular organism is proportional, within certain limits, to the concentration of an essential nutrient-e.g., a vitamin. This has resulted in the development of a wide variety of microbiological methods for the determination of vitamins, amino-acids, etc. Growth may be assessed either nephelometrically or, if the organism is an active acid-producer and the medium is highly buffered, by the amount of titratable acid produced. Such methods are extremely sensitive and little preliminary manipulative work is usually required.

The usual chemical methods for the determination of members of the vitamin B complex are, owing to their complexity, generally outside the scope of the hospital biochemical laboratory. Microbiological methods, on the other hand, owing to their greater simplicity, are more adaptable to hospital needs. Also multiple determinations with comparatively little extra labour may be carried out.

The determination of nicotinic acid and riboflavin in urine by microbiological methods has been examined. There have been many published methods, but those of Barton-Wright and Booth (1943) for riboflavin and Barton-Wright (1944, $1945)$ for nicotinic acid have with certain modifications proved to be satisfactory.

\section{Procedure}

Stock cultures are carried as stabs on the following medium:

$\begin{array}{llllll}\text { Yeast extract } & \ldots & \ldots & 1.0 \text { per cent } \\ \text { Glucose } & \ldots & \ldots & \ldots & 0.5 & \text { per cent } \\ \text { Sodium acetate } & \ldots & \ldots & 0.6 & \text { per cent } \\ \text { Agar } & \ldots & \ldots & \ldots & 1.5 & \text { per cent } \\ p \mathrm{H} & \ldots & \ldots & \ldots & \mathbf{6 . 8}\end{array}$

After inoculation, cultures are incubated at $37^{\circ} \mathrm{C}$. for 48 hours and then preserved in a refrigerator. Stock cultures are renewed at fortnightly intervals.

TABLE I

\begin{tabular}{l|l}
\hline \multicolumn{1}{c|}{ Organism used } & \multicolumn{1}{c}{ Vitamin } \\
\hline $\begin{array}{l}\text { Lactobacillus helveticus (casei) } \\
\text { N.C.T.C. No. 6375 } \\
\text { Lactobacillus arabinosus 17/5 } \\
\text { N.C.T.C. No. 6376 }\end{array}$ & Riboflavin \\
\hline
\end{tabular}

Normal urine contains a number of pyridine compounds closely related to nicotinic acid-namely, nicotinic acid, nicotinamide, nicotinuric acid, $\mathrm{N}^{1}$ methylnicotinamide, and trigonelline. The response of $L$. arabinosus $17 / 5$ to nicotinic acid, nicotinamide, and nicotinuric acid is proportional to their nicotinic acid content (Snell and Wright, 1941). The other two pyridine derivatives show no activity towards this organism.

The present writers have found that the dependence of their own cultures on these organisms for these vitamins has remained unchanged over a period of twelve months.

\section{Preparation of Media}

Stock Solutions.-The following stock solutions were prepared:

Photolysed peptone. $-10 \mathrm{~g}$. of peptone and $5 \mathrm{~g}$. of sodium hydroxide are dissolved in $125 \mathrm{ml}$. water and placed in a narrow cylinder about 18 in. from a 
100-watı electric lamp for two to three days. This procedure ensures the complete destruction of all riboflavin in the peptone. Then $7 \mathrm{ml}$. of glacial acetic acid and $3 \mathrm{~g}$. of crystalline sodium acetate are added, the volume made up to $200 \mathrm{ml}$. with water and filtered.

Yeast supplement (riboflavin-free). $-40 \mathrm{~g}$. of basic lead acetate dissolved in $125 \mathrm{ml}$. of water are added to $25 \mathrm{~g}$. of yeast extract in $125 \mathrm{ml}$. of water. The $p \mathrm{H}$ is adjusted to $\mathbf{1 0}$ with ammonia, and the precipitate filtered off. The filtrate after acidification with glacial acetic acid is treated with hydrogen sulphide gas until all the lead is precipitated. The lead sulphide is filtered off, excess hydrogen sulphide is removed by boiling, and the volume made up to $250 \mathrm{ml}$. by the addition of water.

Casein hydrolysate.-A spray-dried product has been used.

Cystine solution. $-1 \mathrm{~g}$. of cystine is added to 250 $\mathrm{ml}$. water containing $1 \mathrm{ml}$. of concentrated hydrochloric acid and the mixture heated until all the cystine has passed into solution.

DL-Tryptophan solution.-1 g. of tryptophan is boiled with $250 \mathrm{ml}$. of water and concentrated hydrochloric acid added until solution is effected. (The synthetic DL-product should be used in preference to the natural L-tryptophan since the latter is often contaminated with vitamins.)

Adenine, guanine, and uracil solution.-0.1 g. of each are added to $100 \mathrm{ml}$. water containing a few drops of concentrated hydrochloric acid. Solution is effected by heat. The final volume should be made up to $100 \mathrm{ml}$. by the addition of water.

Xanthine solution. $-0.1 \mathrm{~g}$. is added to $100 \mathrm{ml}$. water containing a few drops of strong ammonia.

Calcium d-pantothenate solution. $-0.1 \mathrm{~g}$. is dissolved in $100 \mathrm{ml}$. water.

Nicotinic acid solution. $-0.1 \mathrm{~g}$. is dissolved in 100 ml. water. $(1 \mathrm{ml} .=1,000 \mu \mathrm{g}$. nicotinic acid.)

Pyridoxine solution. -0.244 g. pyridoxine hydrochloride is dissolved in $100 \mathrm{ml}$. water.

$\mathrm{p}$-Aminobenzoic acid solution. $-0.1 \mathrm{~g}$. is dissolved in $100 \mathrm{ml}$. water containing $1 \mathrm{ml}$. of glacial acetic acid.

Aneurin solution. $-0.1 \mathrm{~g}$. is dissolved in $100 \mathrm{ml}$. of 2 per cent hydrochloric acid."

Riboflavin solution. $-25 \mathrm{mg}$. of riboflavin is added to a little water and $1 \mathrm{ml}$. of glacial acetic acid and diluted to $1,000 \mathrm{ml}$. with distilled water. This solution, owing to the sensitivity of riboflavin to light, should be preserved in a dark brown bottle. $(1 \mathrm{ml} .=$ $25 \mu$ g.. riboflavin.)

Biotin solution.-An ampoule of $25 \mu \mathrm{g}$. biotin + $1 \mathrm{ml}$. of inorganic solution $A$ is diluted to $250 \mathrm{ml}$. with water.

Inorganic solution A. -25 g. $\mathrm{K}_{2} \mathrm{HPO}_{4}$ and $25 \mathrm{~g}$. $\mathrm{KH}_{2} \mathrm{PO}_{4}$ are dissolved in water and the volume made up to $250 \mathrm{ml}$.
Inorganic solution $B .-10$ g. $\mathrm{MgSO}_{4}, 7 \mathrm{H}_{2} \mathrm{O}, 0.5 \stackrel{\stackrel{\oplus}{\Phi}}{\stackrel{\oplus}{\Phi}}$ $\mathrm{MnSO}_{4}, 4 \mathrm{H}_{2} \mathrm{O}$, and $0.1 \mathrm{~g}$. anhydrous $\mathrm{FeCl}_{3}$ are dis: solved in water containing a few drops of conce trated hydrochloric acid.

The solutions should be prepared with glasf distilled water and preserved in glass-stoppere bottles in a refrigerator. If a few drops of chlor form are added to each and assays are being carrief out frequently, these solutions will keep well.

Media.-Sufficient for 100 tubes is prepared.

\section{TABLE II}

MEDIA PREPARED FROM STOCK SOLUTION AND OTHER SUBSTANCES

\begin{tabular}{|c|c|c|c|}
\hline & & $\begin{array}{c}\text { Riboflavin } \\
\text { assay }\end{array}$ & $\begin{array}{r}\text { Nicotinie } \\
\text { acid assay }\end{array}$ \\
\hline \multirow{2}{*}{\multicolumn{2}{|c|}{$\begin{array}{l}\text { Photolysed peptone solution .. } \\
\text { Spray-dried casein hydrolysate }\end{array}$}} & $100 \mathrm{ml}$ & $-\bar{c}$ \\
\hline & & $25 \overline{m 1}$ & $6 \mathrm{~g}$. \\
\hline \multicolumn{2}{|c|}{$\begin{array}{l}\text { L-Cystine solution } \\
\text { DL-Tryptophan solution }\end{array}$} & $25 \mathrm{ml}$. & $\begin{array}{l}50 \mathrm{ml} . \\
50 \mathrm{ml}\end{array}$ \\
\hline \multirow{2}{*}{\multicolumn{2}{|c|}{ 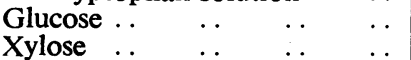 }} & $20 \mathrm{~g}$. & $\begin{array}{l}50 \mathrm{ml} . \\
20 \mathrm{~g} .\end{array}$ \\
\hline & & $1.0 \mathrm{~g}$ & $1 \mathrm{~g}$. \\
\hline \multicolumn{2}{|c|}{ Sodium acetate (hydrated) $\quad$. } & & 33.0 \\
\hline \multicolumn{2}{|c|}{ Riboflavin-free yeast supplement } & $20 \mathrm{ml}$. & \\
\hline \multicolumn{2}{|c|}{$\begin{array}{l}\text { Adenine, guanine, and uracil } \\
\text { solution }\end{array}$} & $10 \mathrm{ml}$. & $\mathrm{ml}$. \\
\hline \multicolumn{2}{|c|}{ Xanthine solution $\quad \ldots \quad \ldots$} & $10 \mathrm{ml}$. & $10 \mathrm{ml}$. \\
\hline \multicolumn{2}{|c|}{$\begin{array}{l}\text { Calcium } d \text {-pantothenate solu- } \\
\text { tion }\end{array}$} & $1 \mathrm{ml}$. & $1 \mathrm{ml}$. \\
\hline \multicolumn{2}{|l|}{ Nicotinic acid solution } & $1 \mathrm{ml}$. & - \\
\hline \multicolumn{2}{|c|}{ Pyridoxine solution $\ldots \quad \ldots$} & $1 \mathrm{ml}$. & $1 \mathrm{ml}$. \\
\hline \multicolumn{2}{|c|}{$\begin{array}{l}\text { p-Aminobenzoic acid solution } \\
\text { Aneurin solution }\end{array}$} & $4 \mathrm{ml}$. & $1 \mathrm{ml}$. \\
\hline $\begin{array}{ll}\text { Riboflavin solution } & \ldots\end{array}$ & $\begin{array}{l}\cdots \\
\ldots\end{array}$ & - & $8 \mathrm{ml}$. \\
\hline Biotin $\ldots$ & & - & $4 \mathrm{ml}$. \\
\hline Sodium chloride & & 5.0 & \\
\hline Ammonium sulphate & & $3.0 \mathrm{~g}$ & 3.0 \\
\hline Inorganic salt solution A & & $5.0 \mathrm{ml}$. & $5.0 \mathrm{ml}$ \\
\hline Inorganic salt solution B & . & $5.0 \mathrm{ml}$. & $5.0 \mathrm{ml}$ \\
\hline Glass-distilled water to & . & $500 \mathrm{ml}$. & $500 \mathrm{ml}$ \\
\hline
\end{tabular}

The $p \mathrm{H}$ of the media is adjusted to 6.8 by the add? tion of sodium hydroxide solution using bromothym blue as external indicator, or indicator test papers. After filtration through a No. 1 Whatman filter paper. a few drops of chloroform are added and the medio preserved in a refrigerator. Under such conditionis, especially if assays are carried out at frequent inte? vals, the prepared media will keep. well.

Before use a portion of the medium should be heated to boiling point to remove chloroform.

Preparation of Assay Tubes.-Universal containef with metal caps and rubber seals were used in place of test tubes with cotton-wool plugs. Aftę use tubes should be cleaned out with tap water anf rinsed with glass-distilled water. It was found corf venient to keep a set of tubes for one particular assag and to number the containers with a glass diamond. $\frac{\sigma}{\sigma}$

In each series of assays blanks and a series of stan dards were prepared in duplicate. Although litt: 
variation in the standard curves has been encountered over a period of twelve months, such controls are essential as a check on the non-varying dependence of the organism for the particular vitamin under investigation and the constancy of the medium.

Rihoflavin.-Assay tubes were prepared as follows :

Blanks. $-5 \mathrm{ml}$. of water and $5 \mathrm{ml}$. of medium were measured into each tube.

Standards.-Standards containing $0.05,0.10,0.15$, and $0.20 \mu \mathrm{g}$. of riboflavin were prepared.

The standard solution, $25 \mu \mathrm{g} . / \mathrm{ml}$., is diluted so that $1 \mathrm{ml}$. contains $0.05 \mu \mathrm{g}$. This solution should be prepared fresh before use.

\section{TABBLE III}

QUUANTITIES

\begin{tabular}{c|c|c|c}
\hline $\begin{array}{c}\text { Standard } \\
\text { containing } \\
\text { riboflavin } \\
(\mu \text { z. })\end{array}$ & $\begin{array}{c}\text { Medium } \\
\text { (ml.) }\end{array}$ & $\begin{array}{c}\text { Dilute } \\
\text { riboflavin } \\
\text { standard } \\
\text { solution } \\
\text { (ml.) }\end{array}$ & Water \\
\hline 0.05 & 5 & 1 & 4 \\
0.10 & 5 & 2 & 3 \\
0.15 & 5 & 3 & 2 \\
0.20 & 5 & 4 & 1 \\
\hline
\end{tabular}

Urine - $1,0.5,0.25$, and $0.1 \mathrm{ml}$. of urine diluted to $5 \mathrm{ml}$. were added to $5 \mathrm{ml}$. of medium. These quantities will cover all concentrations of riboflavin likely to be encountered in urine except when large quantities of riboflavin-for example, $10 \mathrm{mg}$.- have been administered. After oral administration of $10 \mathrm{mg}$. riboflavin, an additional $0.05,0.025$, and 0.01 ml. of urine diluted to $5 \mathrm{ml}$. should also be included.

Nicotinic Acid.-Assay tubes were prepared as follows :

Blanks. $-5 \mathrm{ml}$. of water and $5 \mathrm{ml}$. of medium were measured into each tube.

Standards.-Standards containing $0.05,0.10,0.15$, $0.20,0.25$, and $0.30 \mu \mathrm{g}$. of nicotinic acid were prepared. The standard solution, $1,000 \mu \mathrm{g} . / \mathrm{ml}$., is diluted so that $1 \mathrm{ml}$. contains $0.01 \mu \mathrm{g}$. nicotinic acid. This solution should be prepared fresh before use.

TABLE IV

QUANTITIES

\begin{tabular}{c|c|c|c}
\hline $\begin{array}{c}\text { Standard } \\
\text { containing } \\
\text { nicotinic } \\
\text { acid }\end{array}$ & $\begin{array}{c}\text { Medium } \\
\text { (ml.) }\end{array}$ & $\begin{array}{c}\text { Dilute } \\
\text { nicotinic acid } \\
\text { standard } \\
\text { solution } \\
\text { (ml.) }\end{array}$ & Water \\
\hline 0.05 & 5 & 0.5 & 4.5 \\
0.10 & 5 & 1.0 & 4.0 \\
0.15 & 5 & 1.5 & 3.5 \\
0.20 & 5 & 2.0 & 3.0 \\
0.25 & 5 & 2.5 & 2.5 \\
0.30 & 5 & 3.0 & 2.0 \\
\hline
\end{tabular}

Urine - $-0.5,0.25,0.1$, and. $0.05 \mathrm{ml}$. of urine diluted to $5 \mathrm{ml}$. were added to $5 \mathrm{ml}$. of medium. These quantities will cover all concentrations of nicotinic acid likely to be encountered in urine.

Filled tubes were sterilized by placing in a steamer or a hot-air oven at $100^{\circ} \mathrm{C}$. for one hour. Autoclaving was found to produce intense brown colorations which rendered subsequent titration with alkali very difficult to assess.

\section{INOCULATION}

Riboflavin. $-5 \mathrm{ml}$. of riboflavin medium and $5 \mathrm{ml}$. of distilled water containing $0.25 \mu \mathrm{g}$. of riboflavin were introduced into a universal container and sterilized as described above. The medium was inoculated with a portion of the stock agar stab culture by means of a sterile needle and incubated for 18 to 20 hours at $37^{\circ} \mathrm{C}$. There should be good visible growth at the end of this period. The contents of the container were centrifuged, the supernatant fluid poured off, and $10 \mathrm{ml}$. of 0.85 per cent sterile saline solution added; 20 drops of this suspension were mixed with $10 \mathrm{ml}$. of 0.85 per cent sterile saline solution, and 1 drop of this latter suspension added to each of the assay tubes.

Nicotinic Acid. $-5 \mathrm{ml}$. of nicotinic acid medium and $5 \mathrm{ml}$. of distilled water containing $0.5 \mu \mathrm{g}$. of nicotinic acid were introduced into a universal container and sterilized as described above. It was inoculated with a portion of the stock agar stab culture by means of a sterile needle and incubated at $37^{\circ} \mathrm{C}$. until good visible growth was observed. Usually this is attained after 18 hours, but on some occasions 36 hours' incubation is necessary. The contents of the container were centrifuged, the supernatant fluid poured off, and $10 \mathrm{ml}$. of 0.85 per cent sterile saline solution added; 20 drops of this suspension were mixed with $100 \mathrm{ml}$. of 0.85 per cent sterile saline solution, and 1 drop of this latter suspension added to each of the assay tubes.

\section{INCUBATION}

Assay tubes were incubated at $37^{\circ} \mathrm{C}$. for three days. Exact times are unnecessary since both unknowns and standards are subjected to the same treatment. At the end of the incubation period the lactic acid in the containers was titrated with $0.1 \mathrm{~N}$-sodium hydroxide using bromothymol blue as indicator.

\section{Calculation}

A graph was constructed in which content of riboflavin (or nicotinic acid) in $\mu \mathrm{g}$. was plotted against ml. $0.1 N$-sodium hydroxide used in the respective titrations (see Figs. 1 and 2). Blanks should require less than $1 \mathrm{ml}$. of $0.1 \mathrm{~N}$-sodium hydroxide to effect neutralization. The riboflavin (or nicotinic acid) content of the unknowns was then read off the graph using the titrimetric values. It has been found possible to obtain readings from at least two urinary levels, 
differences never exceeding 15 per cent-i.e., between the limits of

$$
\begin{aligned}
& 0.05-0.20 \mu \mathrm{g} \text {. riboflavin } \\
& \text { and } \\
& 0.05-0.30 \mu \mathrm{g} \text {. nicotinic acid. }
\end{aligned}
$$

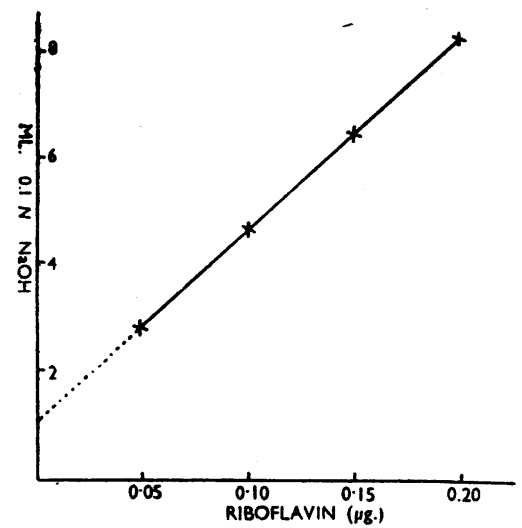

Fig. 1.-Assay of riboflavin.

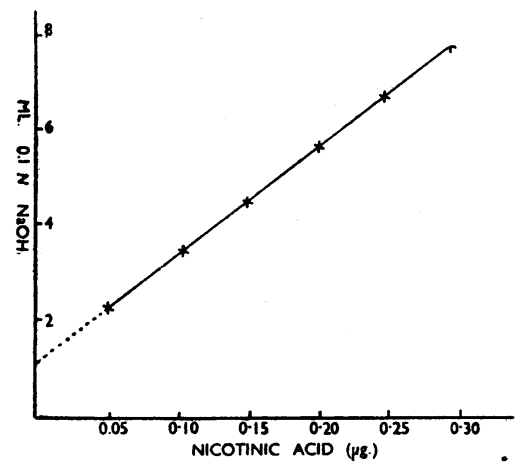

FIG. 2.-Assay of nicotinic acid.

More precise but more laborious methods of calculation have been suggested by Wood (1945, 1946). The normal excretion of these vitamins in urine is so wide and small differences at present of so little significance that in routine investigations there is little to be gained by such methods.

\section{Experimental}

Owing to the lability of riboflavin to light and alkali, urine passed over a period of 24 hours was collected in a dark brown bottle containing $5 \mathrm{ml}$. of glacial acetic acid. When it was necessary to keep the specimen for a longer period it was kept in a refrigerator. The stability of riboflavin and nicotinic acid in urine under such conditions was examined. Urines were assayed initially and 28 days later. From the results shown in Table V it will be seen that there was little change in the concentrations.
The effect of mild acid hydrolysis had little effect on the results (Table VI). (To obtain this $\Rightarrow$ ? hydrolysis $5 \mathrm{ml}$. + $0.5 \mathrm{ml}$. concentrated hydrochloric acid were placed in a boiling-water batho

\begin{tabular}{|c|c|c|}
\hline $\begin{array}{l}\text { Riboflavin } \\
\text { (Test No.) }\end{array}$ & $\begin{array}{c}\text { Initially } \\
(\mu \mathrm{g} . \\
\text { litre })\end{array}$ & $\begin{array}{l}\text { After } 1 \text { month's } \\
\text { preservation } \\
\text { ( } \mu \text { g./litre) }\end{array}$ \\
\hline $\begin{array}{l}1 \\
2 \\
3 \\
4\end{array}$ & $\begin{array}{l}825 \\
825 \\
400 \\
600 \\
\end{array}$ & $\begin{array}{l}800 \\
850 \\
420 \\
650 \\
\end{array}$ \\
\hline $\begin{array}{l}\text { Nicotinic } \\
\text { acid } \\
\text { (Test No.) }\end{array}$ & $\begin{array}{c}\text { Initially } \\
(\mu g . \\
\text { litre })\end{array}$ & $\begin{array}{l}\text { After } 1 \text { month's } \\
\text { preservation } \\
(\mu \mathrm{g} . / \text { litre })\end{array}$ \\
\hline $\begin{array}{l}1 \\
2 \\
3 \\
4 \\
5 \\
6\end{array}$ & $\begin{array}{r}430 \\
1,650 \\
250 \\
570 \\
850 \\
350\end{array}$ & $\begin{array}{r}370 \\
1,800 \\
220 \\
600 \\
875 \\
380\end{array}$ \\
\hline
\end{tabular}

TABLE V STABILITY OF RIBOFLAVIN AND NICOTINIC ACID IN' URINE

for one hour, cooled, and neutralized by the addition of sodium hydroxide.) This is in accordance with the fact that riboflavin is excreted in the free state and that nicotinic acid, nicotinamide, and $\frac{\mathrm{O}}{\mathrm{O}}$

TABLE VI

\begin{tabular}{|c|c|c|}
\hline & $\begin{array}{c}\text { Befọre } \\
\text { hydrolysis } \\
\text { ( } \mu \mathrm{g} . / \text { litre) }\end{array}$ & $\begin{array}{l}\text { After acid } \\
\text { hydrolysis } \\
(\mu \mathrm{g} . / \text { litre) }\end{array}$ \\
\hline Riboflavin & $\begin{array}{r}805 \\
170 \\
105 \\
70 \\
410\end{array}$ & $\begin{array}{r}800 \\
137 \\
105 \\
60 \\
380\end{array}$ \\
\hline Nicotinic acid & $\begin{array}{r}1,100 \\
430 \\
430 \\
1,650 \\
570\end{array}$ & $\begin{array}{r}950 \\
380 \\
480 \\
1,650 \\
540\end{array}$ \\
\hline
\end{tabular}

EFFECT OF MILD ACID HYDROLYSIS ON THE MICROBIOLOGICAL을 ASSAY OF RIBOFLAVIN AND NICOTINIC ACID IN HUMAN URINE

nicotinuric acid exert equivalent responses towards L. arabinosus $17 / 5$.

Recoveries of added riboflavin and nicotinic acid were found to be quantitative (Table VII). The initial content of riboflavin was found to be effec-:tively removed by the addition of alkali and ${ }^{-}$ exposure to the light of a 100-watt electric lamp $\overrightarrow{\mathbb{D}}$ for four days. It was neutralized by the addition $\frac{\rho}{\mathbb{O}}$ of hydrochloric acid.

In many of the chemical methods employed for the estimation of riboflavin and nicotinic acid, 8 
TABLE VII

RECOVERY OF RIBOFLAVIN AND NICOTINIC ACID ADDED TO URINE

\begin{tabular}{|c|c|c|c|c|c|c|c|c|c|c|}
\hline $\begin{array}{l}\text { Test } \\
\text { No. }\end{array}$ & $\begin{array}{l}\text { Riboflavin } \\
\text { added } \\
\text { ( } \mu \text { g./litre) }\end{array}$ & $\begin{array}{l}\text { Riboflavin } \\
\text { recovered } \\
\text { ( } \mu \text { g./litre) }\end{array}$ & $\begin{array}{l}\text { Test } \\
\text { No. }\end{array}$ & $\begin{array}{c}\text { Riboflavin } \\
\text { added } \\
\text { ( } \mu \text { g./litre) }\end{array}$ & $\begin{array}{c}\text { Riboflavin } \\
\text { recovered } \\
(\mu \mathrm{g} . / \text { litre })\end{array}$ & $\begin{array}{l}\text { Test } \\
\text { No. }\end{array}$ & $\begin{array}{l}\text { Initially } \\
(\mu \mathrm{g} . / \text { litre })\end{array}$ & $\begin{array}{c}\text { Nicotinic } \\
\text { acid added } \\
(\mu \mathrm{g} . / \text { litre })\end{array}$ & $\underset{(\mu \mathrm{g} . / \text { litre })}{\text { Final }}$ & $\begin{array}{l}\text { Nicotinic acid } \\
\text { recovered } \\
\text { ( } \mu \text { g./litre) }\end{array}$ \\
\hline $\begin{array}{l}1 \\
2 \\
3 \\
4 \\
5 \\
6 \\
7\end{array}$ & $\begin{array}{r}50 \\
100 \\
50 \\
100 \\
50 \\
100 \\
50\end{array}$ & $\begin{array}{r}55 \\
115 \\
40 \\
115 \\
55 \\
120 \\
50\end{array}$ & $\begin{array}{r}8 \\
9 \\
10 \\
11 \\
12 \\
13 \\
14\end{array}$ & $\begin{array}{r}150 \\
50 \\
150 \\
100 \\
200 \\
50 \\
100\end{array}$ & $\begin{array}{r}140 \\
55 \\
165 \\
120 \\
200 \\
50 \\
95\end{array}$ & $\begin{array}{l}1 \\
2 \\
3 \\
4 \\
5 \\
6 \\
7 \\
8\end{array}$ & $\begin{array}{r}320 \\
320 \\
2,100 \\
2,100 \\
1,800 \\
1,300 \\
220 \\
220\end{array}$ & $\begin{array}{r}200 \\
400 \\
500 \\
1,000 \\
500 \\
1,000 \\
200 \\
400\end{array}$ & $\begin{array}{r}550 \\
740 \\
2,700 \\
8,100 \\
1,700 \\
2,350 \\
460 \\
650\end{array}$ & $\begin{array}{r}230 \\
420 \\
600 \\
1,000 \\
400 \\
1,050 \\
240 \\
430\end{array}$ \\
\hline
\end{tabular}

* $1 \mathrm{ml}$. of of photolysed urine used in each recovery.

absorption on varied types of material is used as a preliminary to the final fluorometric or colorimetric evaluation. The effect of urinary deposits was investigated. Assays for riboflavin and nicotinic acid were carried out on the urine which had been well shaken, and on the supernatant fluid after centrifugalization. The results shown in Table VIII indicate that appreciable amounts of riboflavin were absorbed on the urinary deposits. Urinary deposits are variable and it is quite possible that such do exist and can absorb appreciable amounts of nicotinic acid. These experi-

TABLE VIII

ABSORPTION OF RIBOFLAVIN AND NICOTINIC ACID ON URINARY DEPOSITS

\begin{tabular}{c|c|c}
\hline & $\begin{array}{c}\text { Whole urine } \\
(\mu \mathrm{g} . / \text { litre) }\end{array}$ & $\begin{array}{c}\text { Centrifuged urine } \\
\text { (supernatant } \\
\mu \mathrm{g} . / \text { litre) }\end{array}$ \\
\hline $\begin{array}{c}\text { Riboflavin } \\
1\end{array}$ & 95 & 50 \\
2 & 65 & 40 \\
3 & 100 & 70 \\
\hline $\begin{array}{c}\text { Nicotinic acid } \\
1\end{array}$ & 3,000 & 2,600 \\
2 & 750 & 700 \\
3 & 1,060 & 1,160 \\
\hline
\end{tabular}

ments indicate that in vitamin B assays urines containing deposits should be so treated that representative samples may be measured.

Riboflavin $10 \mathrm{mg}$. and nicotinamide $50 \mathrm{mg}$. were administered to patients who had no evidence of deficiency of these vitamins.* Excretion of these vitamins before and during the first 24 hours after administration was determined (Table IX). Increased excretion of riboflavin accounted for

- The test dose also included $5 \mathrm{mg}$. aneurin and $200 \mathrm{mg}$. ascorbic acid. approximately 50 per cent of the administered vitamin. This is in accordance with the findings of Melnick et al. (1945), who used fluorometric methods of analysis. There was little change in the excretion of nicotinic acid. This is in accor-

TABLE IX

RIBOFLAVIN AND NICOTINIC ACID

\begin{tabular}{|c|c|c|c|}
\hline $\begin{array}{l}\text { Case } \\
\text { No. }\end{array}$ & - & $\begin{array}{l}\text { Riboflavin } \\
(\mu \mathrm{g} . / \text { diem })\end{array}$ & $\begin{array}{c}\text { Nicotinic acid } \\
(\mu \mathrm{g} . / \mathrm{diem})\end{array}$ \\
\hline 1 & $\begin{array}{l}\text { Before test dose } \\
\text { After ", ", }\end{array}$ & $\begin{array}{r}920 \\
6,030\end{array}$ & $\begin{array}{l}0.84 \\
0.34\end{array}$ \\
\hline 2 & $\begin{array}{l}\text { Before test dose } \\
\text { After , , }\end{array}$ & $\begin{array}{r}570 \\
4,374\end{array}$ & $\begin{array}{l}0.76 \\
1.38\end{array}$ \\
\hline 3 & $\begin{array}{l}\text { Before test dose } \\
\text { After , , , }\end{array}$ & $\begin{array}{r}468 \\
5,890\end{array}$ & $\begin{array}{l}0.40 \\
0.53\end{array}$ \\
\hline 4 & $\begin{array}{l}\text { Before test dose } \\
\text { After , , , }\end{array}$ & $\begin{array}{r}450 \\
4,480\end{array}$ & $\begin{array}{l}1.17 \\
0.57\end{array}$ \\
\hline 5 & $\begin{array}{l}\text { Before test dose } \\
\text { After ", ", }\end{array}$ & $\begin{array}{r}200 \\
4,500\end{array}$ & $\begin{array}{l}0.97 \\
1.12\end{array}$ \\
\hline
\end{tabular}

dance with the findings of Melnick et al. (1940) and Huff and Perlzweig (1943) that, following ingestion of nicotinamide, $N^{1}$ methylnicotinamide is the main metabolite excreted in the urine.

\section{Summary}

Factors that influence the microbiological determination of riboflavin and nicotinic acid derivatives in urine have been investigated.

\section{REFERENCES}

Barton-Wright, E. C., and Booth, R. G. (1943). Biochem. J., 37, 25. Barton-Wright, E. C. (1944). Biochem. J., 38, 314

Barton-Wright, E. C. (1945). Analyst, 70, 283.

Huff, J. W., and Perlzweig, W. A. (1943). J. biol. Chem., 150, 483.

Melnick, D., Hochberg, M., and Oser, B. L. (1945). J. Nutrit., $30,67$. Melnick, D., Hochberg, M., and Oser, B. L. (1945). J. Nutrit., 30, 67.
Melnick, D., Robinson, W. D., and Field, H., Jr. (1940). J. biol. Chem., 136, 145.

Snell, E. E., and Wright, L. D. (1941). J. biol. Chem., 139, 675

Wood, E. C. (1945). Nature, 155, 632.

Wood, E. C. (1946) Analyst, 71, 1 